\title{
Allocating the Book Budget: Equity and Economic Efficiency
}

Gold's cost-benefit model for allocating the book budget is critiqued from the point of view of practicability, economic theory, and equity. It is concluded that allocative formulas are preferred alternatives for distributing the book budget among departmental funds. Economic efficiency via cost-effectiveness analysis is suggested as potentially useful for within fund acquisition of library-resource units.

$\mathbf{T}$ as a brief discussion of Gold's marginal cost-benefit model for allocating the book budget among academic departments. ${ }^{1}$ However, it soon became apparent that a more lengthy paper was necessary. Several features of cost-benefit analysis must be explored in order to put the marginal cost-benefit model in perspective. Furthermore, Gold advocates economic efficiency versus equity, an issue that challenges a fundamental premise by which librarians have traditionally allocated the book budget. This problem brings up the role of allocative formulas and their validity. Finally, there was the need to comment on costeffectiveness analysis and its potential impact on economically efficient acquisition of library-resource units.

\section{Difficulties of Cost-Benefit Analysis}

In their oft-cited review article, Prest and Turvey list several limitations in principle to cost-benefit analysis. ${ }^{2}$ Among these is the problem of intangible benefits; that is, those benefits that do not

Joseph J. Kohut is science librarian and John F. Walker is associate professor of economics, Portland State University, Portland, Oregon. lend themselves to quantification. The scope of this problem is magnified for complex social institutions/programs wherein there are many different beneficiaries and many kinds of benefits, both personal and social. Within this category are academic libraries with multiple objectives (except in the most general sense) and diverse readership with diverse needs. The problem of benefit enumeration is, therefore, exceedingly difficult, if not impossible. Nonetheless, the analysis demands that all benefits, many of which are subtle and indirect, be listed without double counting.

The evaluation of intangible benefits must also be considered, for it is insufficient that they be merely noted. But how does one put a numeric value on such personal reading experiences as esthetic appreciation, joy of discovery, insight, boredom? Or on social benefits such as the educative value of reading, information as a community resource? Even if some benefits are quantifiable, they must be valued in dollars. Most of these are not money-valued benefits; that is, their worth has not been established in a competitive marketplace. It may, with considerable effort, be possible to assign shadow prices or arbitrary 
weights, but it is doubtful whether these would add much to decisions made on the basis of intuition or experience. ${ }^{3}$ In any case, incommensurables cannot be ignored, a danger not uncommon in cost-benefit analyses. On the other hand, bias must not be introduced by under or over-evaluation. To simply list incommensurables separately is inadequate if the bulk of the benefits cannot be assigned reasonable dollar values. In his summation of the first Brookings conference on government expenditures, Dorfman concludes:

The practitioners were very skeptical and inclined to doubt whether the most important social effects of government investments could ever be appraised quantitatively by cost-benefit analysis or any other formalized method. One of them likened the problem to appraising the quality of a horseand rabbit-stew, the rabbit being cast as the consequences that can be measured and evaluated numerically, and the horse as the amalgam of external effects, social, emotional, and psychological impacts, and historical and aesthetic considerations that can be adjudged only roughly and subjectively. Since the horse was bound to dominate the flavor of the stew, meticulous evaluation of the rabbit would hardly seem worthwhile. ${ }^{4}$

The rabbit is neither sufficiently large nor the horse sufficiently small to make a significant quantitative impression on the book-budget stew.

There is yet another impediment to describing the marginal-benefit curves demanded by Gold. Benefits must be measured annually for each curve, one for each academic department. There must then be a single, objective valuemeasure of benefit applicable to all departments. This point introduces the problem of incomparabilities. The university is a pluralistic society with a complex mix of program objectives (e.g., teaching; research; providing a liberal education; training businessmen, teachers, etc.). To take only major reference tools, for example, would all patrons agree as to the absolute value of the Art Index, Business Periodicals Index, Chemical Abstracts, Bibliography of the Modern Language Association? Because the value of intangible benefits is primarily dependent on one's point of view, there is no single measure that could be agreed upon. Willis $\mathrm{H}$. Shapeley has commented:

In theoretical discussions, it is nice to visualize a curve, with "decisions" being made by picking the maximum or something that is lower or higher than something else. But for utility in the real world of decision-making, agreement is needed, not only on the many inputs to the measure, but also on the validity of the measure itself, including the underlying theoretical concepts and method of calculation. The possibilities of getting a measure with enough objectivity so that people whose interests are going to be adversely affected will accept it as a judge or a major tool in the decisionmaking seem to me very small indeed. ${ }^{5}$

It is, therefore, naive to assume that fundamental differences in outlook among the diverse groups comprising a university can be resolved and an objective value-measure of benefit devised. How then can the library, which is obligated to support this heterogeneous group of users, all of which are competing for library resources, presume to make the value judgments necessary to produce a cost-beneficial solution?

In addition to these problems relating to the vertical axis of Gold's marginal cost-benefit model is a major difficulty with the horizontal axis. There must be a uniform measure of output; that is, a unit of consistent size and quality. Since there is no good correlation between quantity and quality of literature output, such a measure cannot be 
derived. It is unreasonable, for example, to expect that a long novel (or part thereof) is always "better" than a short poem. Moreover, there is the difficulty expressed above in that not everyone would always agree on what is "better" because "better" is a subjective concept. Even if these obstacles could somehow be overcome, such a hypothetical unit would be unworkable in practice. $\mathrm{Li}$ brarians must deal with library-resource units. The unit of output of the book budget is $a$ monograph, $a$ serial, etc. Though discrete items, they are nonequivalent, nor were they intended to be. To put it another way: generation of the marginal-benefit curves requires that library-resource units be homogeneous. Neither are they, nor can they be homogeneous because virtually all are copyrighted. In this sense homogeneity is illegal.

The notion of copyright raises the question of monopoly. Monopoly prices disturb the conditions of Pareto optimality and create inefficiencies in Gold's sense of the word. The rules of "the general theory of the second best" apply when any element assumed by the model is not fulfilling the rules of general economic equilibrium. Though the rules of second best are not well developed, it is a fair interpretation that if all conditions for equilibrium cannot be met, then none of them should be enforced. 6 Thus, Gold's "rules" for allocating the book budget, which are imitations of the conditions for general equilibrium in a competitive economy, may produce less efficiency, not more, since elements of monopoly are inescapable.

In effect, Gold is advocating a planning programming and budgeting system (PPBS) for every subject department of the library. A standard objection to such an approach is that a full cost-benefit analysis of any public expenditure is meaningful only when compared to similar studies of all other expenditures. That is, a comparative study of each book in every library is theoretically required. The time and cost of such a study would be overwhelming, particularly when spillovers, uncertainties, inadequate information, time-stream cost-benefit discounting, and other difficulties create distortions unless compensated. ${ }^{7}$

Finally, economists cannot agree on the criteria to judge a professionally acceptable cost-benefit analysis. Harburger observed "the need for an accepted set of professional standards for this type of study should be obvious." The purpose of Harburger's article was to suggest three criteria. One of these criteria has been challenged by Boadway, who concluded that it improperly ignored equity relations which must be weighted on "non-economic grounds." Since economists can't agree on the criteria to judge a good cost-benefit analysis, how can they expect librarians to do so?

\section{Economic EFFicIENCY AND EQuity}

There appears to be a failure by Gold to recognize that allocation of library-resource units is not so much a capital investment project as it is one of general welfare economics. In business it is obvious that profits (benefits) should be maximized for the concern. In the matter of "public" fund expenditures, such as a library, where there are many beneficiaries, the issue is not so clear cut. Moreover, the library's goal is to produce mainly intangible benefits, not to increase future income. When benefits are diffuse, mainly noneconomic, and nontransferable into standard units of output, the cost-benefit approach is inapplicable.

In general welfare economics there are really two questions that must be answered: (1) Is the program economically efficient? and (2) Is the distribu- 
tion of resources "desirable"? According to Weisbrod:

... advice by economists to decision makers tends to be restricted to questions of the first type. At the same time actual decisions do, and should, also reflect questions of the second type. As a result, economists often are disappointed that their advice carries little weight, and decision makers are disappointed that economists do not provide more complete advice. ${ }^{10}$

Whether economic efficiency is sufficient in itself is a moot point. The fact is that library administrators are concerned about equity and the direction of collection development. These concerns have been evident at least since allocation by academic department became common at the turn of the century.

Part of the problem here is a confusion of roles between the analyst and the decision maker. According to Bonnen, for example, the question of who should benefit is a normative matter involving value judgments that an economist as a scientist is not in a position to make. ${ }^{11}$ Similarly, the need for explicit decisions in allocation of the book budget is not obviated by an assignment of costs and benefits and simply allowing the resources to fall as they may. In truth, cost-benefit analysis is not even a politically neutral tool, for like it or not there will likely be pressures depending on whose ox is being gored.

The danger that the analysts will dictate decisions is very real for:

We live in a culture that worships quantities. A computer printout on tissue paper can in a political environment thicken into an arras behind which no one can see. It insulates against common sense. A man who says, "My experience and judgment tells me this should be done," is hard put to defend his opinion against a man who says, "The computer tells me that should be done." In which of these men it is wise to put one's faith depends on how much of the hard-bitten reality has been conveyed to the computer. In other words, the opportunity cost of benefit-cost analysis, narrowly defined can be the debilitation of the power of judgment. ${ }^{12}$

We do not mean to deny the utility of mathematical models, or even cost-benefit analysis where applicable. But their limitations must be realized, and the analysis alone must never be allowed to preempt good judgment in matters that are largely "noneconomic" and "nonscientific."

\section{Allocating BY Formula}

Gold seems to think that inefficiencies will result by any allocative model not in accord with the rules governing the general economic equilibrium. In fact, it has been argued that quick rules of thumb about pricing and purchasing that keep costs of decisions down actually increase the probability that the system acts the way the theory predicts. ${ }^{13}$ Gordon concluded that to the extent "rules of thumb" used by decision makers are inconsistent with theory, it is because the theory is weak. ${ }^{14}$ Quick rules of thumb or formulas for allocating the book budget are not, therefore, without economic efficiency. In fact, these formulas meet another frequently mentioned justification for cost-benefit analysis. That is, they make explicit factors formerly unconsidered or only intuitively sensed in the decision-making process.

Ever since the Clapp-Jordan formula for estimating liminal adequacy of academic libraries, value judgments expressed by weighing factors have been an important aspect of formula budgeting. In general, four major factors have been considered in the allocative formula: subjective judgments based on collection evaluations and historical inequities, size of academic departments, 
level of program and usage, and literature size. All emphasize the importance of equity.

Collection evaluation and standards were common long before allocation by formula. The literature on this topic is extensive and varied. ${ }^{15}$ The process is obviously subjective and dependent on knowledgeable analysts. An element of "objectivity" may be introduced by using numeric guidelines for allocating book funds according to preestablished, arbitrary standards of adequacy. It is generally assumed that there is some correlation between the size of a collection and its value.

Goyal stressed the importance of department size. ${ }^{16} \mathrm{He}$ initially recognized the importance that society and the university attach to the work of a given department. The problem is greatly simplified by assuming that society and the university attach equal importance to the work of each department and that bias in favor of one or another would be expressed in the size and growth of such departments. Thus, allocation by departmental size allows librarians to avoid independent value judgments between incomparabilities (e.g., whether physics is more important than philosophy). The judgment is, in fact, in large part made for society and the library by the university, including the students.

The organizational factor in allocation has been further refined by describing departments according to level of program. Burton, for example, used weighing factors based on library usage (as measured by circulation data) for lower and upper division undergraduates, graduate students, and faculty. ${ }^{17}$ Thus, usage is considered in conjunction with department size and composition.

McGrath described departments by their curriculum which he related to annual literature output for each subject. ${ }^{18}$ Literature output and other vari- ables were later submitted to factor analysis as a basis for an allocative formula. ${ }^{19}$ Inherent in the literature-size factor are several assumptions. For example, the potential utility of a given subject literature is proportional to the size of the literature of that field regardless of the subject field. This assumption avoids such irreconcilable arguments as: "One book in physics is worth three books in education." (In fact, no book in education may be considered of any value to a physicist, and vice versa.) The assumption also avoids such unprovable-given the present state of the art-statements as: "Quality control is higher in physics than in education, therefore, physics books are potentially more valuable to a physicist than education books to an educator." Another obvious assumption is: If books/serials are not particularly important to a "reader" in a given subject, then fewer books/serials will be published in that subject than in more literature intensive fields. Or, to put it more simply: Those disinclined to read are disinclined to write. Given the above assumptions, it seems reasonable, from the point of view of equitable access to the literature, that annual literature output for each subject be considered in allocating the book budget. All other factors being equal, each department would receive an equal percentage of the total annual literature output in the corresponding discipline.

Dillehay used the book review literature to compile quantity and cost figures for each subject. ${ }^{20}$ These data were then used in an "augmentation" formula for allocating the book budget. An additional advantage of this approach is a book-review file which is an aide in evaluating proposed purchases. Implicit in Dillehay's model is an understanding that allocation has two aspects: (1) an equitable distribution of books among funding units; and (2) an efficient allo- 
cation of funds within each funding unit. This distribution is in accord with the heterogeneity of users/needs on one level and a more or less homogeneous group of users/needs on another.

Once an equitable distribution of resources is achieved, Kohut is concerned with maintaining the desired balance of library-resource units among the various funding units. ${ }^{21}$ Like Burton, ${ }^{22}$ he recognizes the need to differentiate acquisitions by form of publication (monographs, serials) and that the cost and relative importance of monographs and serials vary by subject. Both employ library-resource units as a basis for allocation. Burton, however, is interested in deriving book-budget requirements to support academic programs. Kohut is concerned with the opposite problem wherein a book budget which is given must be appropriately distributed by form of publication (monograph, serial) within each funding unit. Kohut's correction is intended to adjust for annual changes in the total book budget and/or fluctuations in average monograph and serial costs by subject. (Kohut's correction has been replaced with a simple algebraic solution devised by Gary Sampson, Library, Portland State University. It has been successfully applied in a pilot study using internal cost data generated in the last two years.)

It is assumed that there are no intentional changes in the relative distribution of library-resource units among funding units (e.g., to reflect changes in institutional programs). By tying budget allocation directly to library-resource units, equity is maintained, and an explicit view of collection development and its cost by subject and form of publication is presented.

\section{Book Selection AND ECONOMIC EFFICIENCY}

A strong case for economic efficiency may be made on the level of individual departmental funds. A promising tool is cost-effectiveness analysis, a study designed for single objective problems and more or less homogeneous groups of users and values. Moreover, it avoids the obstacles of disparate benefits and their dollar values. The concern is not with collection worth, but with collection effectiveness (measured by usage) in relation to costs.

Cost-effectiveness analysis may be used as an adjunct to more subjective, traditional means of book selection. Lancaster, for example, considers cost-effectiveness in relation to coverage (collection content) of an information retrieval system..$^{23}$ The calculation of pay-offs is becoming more promising with advances in bibliometrics (e.g., BradfordianZipf distributions, literature obsolescence rates, acquisition characteristics curves, etc.). Such bibliographic studies are becoming a prominent feature of library research. ${ }^{24}$ However, as the possibilities of cost-effectiveness analysis become greater, we must be ever alert to its limitations:

It is important to remember that all analysis of choice falls short of scientific research. No matter how we strive to maintain standards of scientific inquiry or how closely we attempt to follow scientific methods, we cannot turn cost-effectiveness analysis into science. Its objective, in contrast to that of science, is primarily to recommend -or at least to suggest-policy, rather than merely to understand and predict. . . . Human judgment is used in designing the analysis, in deciding what alternatives to consider, what factors are relevant, what the interrelations between these factors are, and what numerical values to choose, and in interpreting the results of the analysis. This fact-that judgment and intuition permeate all analysis-should be remembered when we examine the results that come, with apparent high precision, from analysis. ${ }^{25}$

Together with a recognition of user 
idiosyncracies and the experience, common sense, and intuition of knowledgeable bibliographers, cost-effectiveness analysis may eventually help to improve the economic efficiency of book selection.

\section{Summary}

There are a multitude of difficulties in principle and practice that militate against a cost-benefit resolution to allocating the book budget. In fact, there is disagreement among economists that cost-benefit analysis can ever be done well for complex social institutions. It is, therefore, unreasonable to expect that librarians do the kind of detailed economic analysis that economists themselves do badly. In a more general sense, our quarrel is not with economic efficiency per se, but with those who would make economic efficiency the only rele- vant value. It is prudent to keep in mind the admonition of Wildavsky:

It seems unfair to blame the evangelical economizer for spreading the gospel of efficiency. If economic efficiency turns out to be the one true religion, maybe it is because its prophets could so easily conquer. ${ }^{26}$

In problems of welfare economics, equity must be considered in addition to economic efficiency. Thus, the concept of equity is justly entrenched in the library profession. Though equity is dominant in formula budgeting for books, there are also economic efficiencies realized by such rules of thumb. Furthermore, economic efficiency via cost-effectiveness analysis may have a role in book selection as bibliographic investigations of subject literatures progress.

\section{REFERENCES}

1. Steven D. Gold, "Allocating the Book Budget: An Economic Model," College \& Research Libraries 36:397-402 (Sept. 1975).

2. A. R. Prest and R. Turvey, "Cost-Benefit Analysis: A Survey," Economic Journal 75: 683-735 (Dec. 1975).

3. Roland N. McKean, "The Use of Shadow Prices," in Samuel B. Chase, Jr., ed., Problems in Public Expenditure Analysis (Washington, D.C.: The Brookings Institution, 1968), p.33-77; Julius Margolis, "Shadow Prices for Incorrect or Nonexistant Market Values," in Robert H. Haveman and Julius Margolis, eds., Public Expenditures and Policy Analysis (Chicago: Markham, 1970), p.246-90.

4. Robert Dorfman, "Introduction," in Robert Dorfman, ed., Measuring Benefits of Government Investments (Washington, D.C.: The Brookings Institution, 1965), p.2.

5. Willis H. Shapeley, "Comments" on Frederic M. Scherer, "Government Research and Development Programs," in Robert Dorfman, ed., Measuring Benefits, p.6162.

6. R. G. Lipsey and Kelvin Lancaster, "The General Theory of the Second Best," Review of Economic Studies 24:11-32 (1956).

7. Kenneth S. Allen, Current and Emerging Budgeting Techniques in Academic Librar- ies, Including a Critique of the Model Budget Analysis Program of the State of Washington (Seattle?, 1972). The arguments presented by Allen against PPBS for libraries are valid in the present context.

8. Arnold Harburger, "Three Basic Postulates for Applied Welfare Economics: An Interpretive Essay," Journal of Economic Literature 9:785 (Sept. 1971).

9. R. W. Boadway, "The Welfare Foundations of Cost Benefit Analysis," Economic Journal 84:939 (Dec. 1974).

10. Burton A. Weisbrod, "Income Redistribution Effects and Benefit-Cost Analysis," in Chase, ed., Problems in Public Expenditure Analysis, p.177.

11. James T. Bonnen, "The Absence of Knowledge of Distributional Impacts: An Obstacle to Effective Policy Analysis and Decisions," in Haveman and Margolis, eds., Public Expenditures and Public Policy, p.246-90.

12. Ruth P. Mack, "Comments" on Burton A. Weisbrod in Chase, ed., Problems in Public Expenditure Analysis, p.220-21.

13. Richard V. Clemence, Readings in Economic Analysis, vol. 2, Prices and Production (Cambridge, Mass.: Addison-Wesley, 1950). See the articles by F. Machlup and R. A. Lester.

14. R. A. Gordon, "Short Period Price Determi- 
nation in Theory and Practice," American Economic Review 38:265-89 (June 1948).

15. George S. Bonn, "Evaluation of the Collection,” Library Trends 22:265-304 (Jan. 1974).

16. S. K. Goyal, “Allocation of Library Funds to Different Departments of a UniversityAn Operational Research Approach," College of Research Libraries 34:219-22 (May 1973).

17. Robert E. Burton, "Formula Budgeting: An Example," Special Libraries 66:61-67 (Feb. 1975).

18. William E. McGrath, "Determining and Allocating Book Funds for Current Domestic Buying," College \& Research Libraries 28: 269-73 (July 1967).

19. William E. McGrath, Ralph C. Huntsinger, and Gary R. Barber, "An Allocation Formula Derived from a Factor Analysis of Academic Departments," College \& $R e$ search Libraries 30:51-62 (Jan. 1969).

20. Bette Dillehay, "Book Budget Allocation: Subjective or Objective Approach," Special
Libraries 62:509-14 (Dec. 1971).

21. Joseph J. Kohut, "Allocating the Book Budget: A Model," College \& Research Libraries 35:192-99 (May 1974).

22. Burton, "Formula Budgeting."

23. F. W. Lancaster, "The Cost-Effectiveness Analysis of Information Retrieval and Dissemination Systems," Journal of the American Society for Information Science 22: 12-27 (Jan.-Feb. 1971).

24. Allan D. Pratt, "Libraries, Economics, and Information: Recent Trends in Information Science Literature," College \& Research Libraries 36:33-38 (Jan. 1975).

25. Edward S. Quade, "Introduction and Overview" in Thomas A. Goldman, ed., CostEffectiveness Analysis; New Approaches to Decision-Making (New York: Praeger, 1967 ), p.8.

26. Aaron Wildavsky, "The Political Economy of Efficiency: Cost-Benefit Analysis, Systems Analysis, and Program Budgeting," Public Administration Review 26:308 (Dec. 1966). 